\title{
Knowledge, Communication and the Scottish Enlightenment ${ }^{1}$ \\ Revue de Philosophie Economique/Review of Philosophical Economics, 10(2), 2009, 3-23.
}

\section{Sheila Dow*}

\begin{abstract}
There has been a recent resurgence of interest in the subject of rhetoric, including within economics. The purpose of the paper is to focus on the ideas on rhetoric of Adam Smith and his contemporaries (particularly Hume) in relation to their philosophy and economics, against the background of the Scottish Enlightenment. Discussions of language in Scotland at that time departed from what had become a conventional emphasis either on persuasion or on style in order to focus on a broader notion of communication which encompassed both. This followed from a focus on language differences within a united Britain. But for Smith it also followed from his moral philosophy, whereby communication was important as a vehicle for persuasion in the absence of scope for argument by demonstrable proof. He was thus concerned to set up a system of rhetoric. Smith distinguished between the derivation of (provisional) knowledge by the Newtonian experimental method, and the communication of that knowledge as if it were based on derivation from first principles. Subsequent (mis)interpretation of Smith's economics can be understood as stemming from mistaking the rhetoric for the method, and interpreting first principles as axioms. A fuller understanding of Smith's views on communication and the role of sympathy (through imagination) might have led to different understandings of Smith's economics prevailing.
\end{abstract}

Key words: Adam Smith; rhetoric

JEL codes: B3, B4
*Professor in Economics
Director, SCEME
Department of Economics
University of Stirling
Stirling FK9 4LA
UK

Tel: +44 (0)1786-467474

Fax: +44 (0)1786-467469

e-mail: s.c.dow@stir.ac.uk 
October 2009

\section{Introduction}

The purpose of this paper is to consider the ideas about communication which evolved in Scotland in the eighteenth century, and which still have importance today with the revival of interest in the field. The study of rhetoric has a long history, going back to ancient Greece. In the pre-enlightenment period, rhetorical study had come to focus on literary

criticism. ${ }^{2}$ However, the eighteenth-century ideas on rhetoric in Britain reflected the growth in natural science and the associated preference for a plainer style. ${ }^{3}$ These ideas were developed in Scotland in a distinctive systematic way in being concerned, both with linguistic style from a literary perspective, and with metaphysics, or knowledge about the real world. The resulting synthetic approach to rhetoric was captured, not only in the content, but also in the title, of Adam Smith's (1762-63a) lectures on the subject: Lectures on Rhetoric and Belles Lettres. The aim here is to explore the system of rhetoric put forward by Smith, and to use Smith's own ideas on rhetoric in order to understand his economics and the way in which it has been interpreted. Because Smith was concerned with communication, both linguistic style and form of reasoning played a part in capturing the imagination of the audience.

We will discuss how, because the scientific method itself might differ from the most persuasive way of communicating ideas, the scope for misinterpretation was enhanced. Since scientific method and rhetoric differed for Smith himself, we can understand why Smith could be understood as the father of political economy (including its Austrian and Marxist forms) on the basis of his scientific method, and of general 
equilibrium theory on the basis of his rhetoric. We will consider these general interpretations of his economics in more detail below.

The broader Scottish enlightenment understanding of rhetoric as communication is something which has emerged in much of the modern literature on rhetoric. This is particularly the case in the context of economics, in the work of McCloskey (1985, 1994). ${ }^{4}$ McCloskey traces ideas on communication from classical times, and explores Smith's ideas on rhetoric as expressed in his Lectures on Jurisprudence (Smith 176263b), the Theory of Moral Sentiments (Smith 1759) and the Wealth of Nations (Smith 1776), rather than the Lectures on Rhetoric themselves, illustrating how embedded Smith's ideas on rhetoric were in his theory of knowledge and indeed of human nature, more generally. Others have applied the theory of rhetoric to Smith's own writing. For example Warren Samuels has applied his rhetoric approach (Samuels 1989: Introduction) to an exploration of the different interpretations of Smith himself (Samuels 2009), while Vivienne Brown (1994) compares the rhetoric of the Theory of Moral Sentiments with that of the Wealth of Nations.

The approach to be taken here to presenting Smith's ideas will likewise emphasise the interconnections between different aspects of his oeuvre, drawing on aspects of his context and apparent intentions, but drawing explicitly on the Lectures on Rhetoric and Belles Lettres. Indeed one of Smith's ideas on rhetoric was that, to understand a speaker or author, it is necessary to understand the spirit in which their ideas are being put forward. Here in this notion of an outside observer seeking to understand an author, with sympathy, we seem to have presentiment of the concept of the impartial spectator which he developed in the Theory of Moral Sentiments (something we will come back to 
below). Further, this historiographical approach, developed in modern times by Quentin Skinner (1969), facilitates our study of interconnections by seeing some continuity in an author's thought. But it puts a focus on the author which is challenged by another influential stream within modern rhetorical study. Particularly important for our consideration of Smith is Brown's (1994) thoughtful reading of Smith which emphasises understanding from the point of view of the reader rather than the author. However, as we proceed, we will discuss how Smith addresses issues of understanding among his audiences which allows discussion of different readings. ${ }^{5}$

Smith's mentor and friend, David Hume, also emphasised the role of rhetoric. He refers to 'contentment' with the outcome of enquiry, rather than "truth", and therefore his role in persuading his readers. "There is nothing which is not the subject of debate, and in which men of learning are not of contrary opinions. ... amidst all this bustle 'tis not reason, which carries the prize, but eloquence" (Hume 1739-40: xiv). But it was Smith who developed his thoughts on rhetoric more fully, thoughts which were recorded in the form of notes taken of his lectures in Edinburgh, and later in Glasgow, in the form of the Lectures on Rhetoric and Belles Lettres.

The intellectual context for Smith and Hume was the enlightenment. This development occurred during a time of dramatic change in Scotland, as in the rest of Europe. Agricultural improvement and the beginnings of specialised factory production were increasing wealth and encouraging shifts of population into the cities. This experience raised questions for the newly-emerging social sciences - about how this new system would work economically, socially and morally (Young 1997). To these were added the practical questions for what were called the natural sciences. The result was an 
intellectual ferment. This was compounded in Scotland by political change. The Union of Parliaments in 1707 had shifted the political centre to London, while the 1715 and 1745 Jacobite Rebellions had a profound effect on Scottish society. These were armed rebellions aimed at restoring the Stuart line to the British throne, with most (but not all) support from the Scottish Highlands, whose culture was then actively suppressed when the second rebellion failed. The Scottish Enlightenment thinkers were keen to make their contribution within a British context. Yet, on account of their experience within Scotland (and in Scotland within Britain), they were aware of issues of difference in culture and language in a way which their contemporaries elsewhere were not (Emerson 2008, Dow and Dow, 2008).

Communication was central to all of this. New ideas were being developed, but had to be communicated successfully at a time when the relevant disciplines had not been fully established. The Scottish thinkers were acutely aware of communication problems at a variety of levels (Berry 1974; Howell 1975). The Select Society in Edinburgh, of which Smith and Hume were members, took on the task of promoting southern English as the common language (Buchan 2003, 128-30). Smith and Hume's mentor, Frances Hutcheson, was the first in Scotland to lecture in English rather than Latin (Berry 1974). English was not the first language of Scotland. Most Scots in the Highlands and Islands had been Gaelic speakers, but that language was now banned after the Rebellions. Elsewhere in Scotland the first language was Scots, which could not be readily understood outside Scotland. Smith and Hume travelled widely on the Continent, and strove to speak in a form of English which could be better understood, both there and in England. It was an active matter for debate, how best to speak and write in English. 
But it was not just a matter of successful translation from one language to another (the conduit metaphor of communication). Communication of ideas also involved persuasion with respect to particular understandings of reality. The enlightenment saw its key figures thinking about problems in a totally new way, and this had to be communicated persuasively if others were to follow. But in addition, in Scotland, there was an acceptance that true knowledge was unattainable. What was to be communicated, then, was not "truth", but a way of thinking about the world which made sense in terms of the listener's experience, and which provided solutions to pressing problems. The listener had to be persuaded to accept the speaker's judgment, even at the level of conceptualisation. Communication issues were therefore integral to the theory of knowledge.

In the next section we will explore further the theory of knowledge in the Scottish enlightenment, contrasting it with theories of knowledge elsewhere. We will see the relevance of the ideas on rhetoric which arose from this background when we apply them to Adam Smith himself in the interpretation of his economic writings. In particular, we will see the rhetorical force of the modern interpretation of him as a free-marketeer. This is not just a matter of antiquarian interest. The power of this interpretation has meant that many of Smith's ideas which do not fit into a general equilibrium framework, such as the importance of history, of social convention, of arts, of moral philosophy and indeed about methodology itself, have been lost to modern economics discourse. ${ }^{6} \mathrm{We}$ will see how different interpretations of Smith's use of rhetoric led to different interpretations of his economics. What Smith actually communicated, over the ages, was arguably not what he intended (but he would, at least in retrospect, have understood). 


\section{Scottish Moral Philosophy}

The enlightenment period in Europe is generally characterised as the Age of Reason. Rather than truth being the sole preserve of the Church - the product of revelation science would establish truth by means of human reason. Influenced by René Descartes, the French enlightenment is most closely associated with the privileging of reason. The implication was that the real world could be explained by means of introspection and deductive logic. More important, reason could be used to justify actively changing the world; this period saw the rise of humanism. David Hume grappled with this approach, but eventually concluded that it was not an adequate basis for science. In particular, he concluded that reason could not prove existence, without which science could not begin. However, social convention, built up over centuries of experience, provided the basis for belief in existence. Here we have the beginnings of the Scottish theory of human nature, on which all other knowledge, according to Hume, should be built (see further Dow 2001). What was being put forward was a form of logic which was neither purely inductive nor deductive, but which employed a pluralist approach to knowledge, as in Keynes's subsequent formulation of 'human logic' (see Gerrard 1992). ${ }^{7}$

Indeed a theory of human nature was needed to understand why we seek knowledge in the first place. ${ }^{8}$ Hume and Smith both emphasised sentiment (including moral sentiment, or passion) as the starting point for actions beyond instinct, and for knowledge. Reason came later. They discussed the sense of awe and wonder we experience when we come across something new which we cannot explain (see Smith 1795). This was the focus of Smith's (posthumously published) essay on the History of 
Astronomy (Smith 1795; see further Skinner 1976). This sense of awe and wonder drives us to seek out explanations. The very idea of causal connection itself comes from our own experience; we become accustomed to one thing following another, such as pain whenever we hit our hand, which encourages the idea of cause itself, in that one might cause the other:

It follows, then, that all reasonings concerning cause and effect, are founded on experience, and that all reasonings from experience are founded on the supposition, that the course of nature will continue uniformly the same. We conclude, that like causes, in like circumstances, will always produce like effects.

(Hume 1739-40: 651)

But Hume and Smith argued that the real world is so complex, and the mechanisms so hidden, that we cannot hope to understand fully what these causal mechanisms are. We are driven psychologically, as we would say now, to seek explanations which accord as well as possible with our experience and conventional understandings. But it is in effect the human condition that we cannot reasonably expect to uncover truth.

Having been motivated to find an explanation, the preferred approach was the Newtonian experimental method, as this was understood in Scotland (see Comim 2006; Montes 2006). ${ }^{9}$ Experiments as we now understand them were possible only in the physical sciences; in the social sciences it was history which provided the experimental evidence. Both Hume and Smith made detailed study of a wide range of historical episodes in a wide variety of locations. From this study they derived provisional principles, which would then be confronted with some other example of experience to see 
if it fitted. ${ }^{10}$ If so, the principle was confirmed. If not, the principle required modification. Modifications would be expected for application to different circumstances. This was very different from Descartes's logical deduction from axioms taken to be true, such as his famous "cogito ergo sum". One line of reasoning was derived from experience and was subject to modification in different contexts, while the other was derived from selfevident truths and had universal application. The philosophy of science was fundamentally different. Further, while Descartes relied only on introspection and reason, Smith emphasised other faculties too (see further Dow 2009).

A critical human faculty which assists the process of the formation of theories is the imagination. As Griswold (2006: 23) argues, "Smith presents the imagination as lying at the heart of both 'sympathy' and of intellectual endeavour". The imagination furnished the conjectures which filled in the gaps in the evidence, as well as the theoretical system in which those conjectures were formed. In communicating such theoretical systems, it was not surprising in such an age that Smith should talk about theories as being "imaginary machines". Theories appeal to our experience, but also to our imaginations, by providing simple explanations to ease our sense of wonder, and explanations which are aesthetically appealing (Comim 2006). The invisible hand is an example of metaphor which allows us to understand Smith's notion of a system whereby the unintended consequences of individual actions may produce a beneficial outcome.

The imagination is also exercised through one of its products: sympathy (Smith 1759; see also Raphael 1985). While sympathy is fundamental to social behaviour in Scottish enlightenment thought (and indeed to the notion of identity; see Davis, 2003), it is also important for the mutual relations between author and reader, between speaker and 
audience. Successful communication requires that the writer or speaker attempts to see the matter from the perspective of the reader or audience. As Robert Burns (1786) put it: "O wad some Power the giftie gie us, To see oursels as ithers see us!". ${ }^{11}$ How to communicate ideas in a persuasive manner is the subject of rhetoric, where imagination plays a central role. Let us turn now to focus on Smith's ideas on rhetoric.

\section{Smith's Rhetoric}

Adam Smith's first employment, following attendance at Glasgow University and then Oxford University (where he no doubt improved his command of English), was to offer a series of private lectures in rhetoric in Edinburgh in 1748-9 which, unusually for that time, were delivered in English. Smith was to continue to give these lectures when he took up the Chair in Logic and Rhetoric, and again as Professor of Moral Philosophy, in Glasgow. The London Times (1790) obituary referred to Smith's "pronunciation and style", which were "much superior to what could, at that time, be acquired in Scotland only". At a time when Scottish thinkers were anxious to play on a wider stage, a discussion of language and presentation by someone recognised for his language skills attracted a ready audience.

Indeed much of Smith's lectures concerned linguistic style and how best to communicate clearly (Skinner 1996; Howell 1975). For example, he argued for a plain style, avoiding elaborate figures of speech. While the plain style would reduce the scope for stirring the imagination and thus sympathy by style itself, it opened up scope for engaging sympathy through such devices as metaphors and references to telling episodes (such as the pin factory example with which he opens the Wealth of Nations). ${ }^{12}$ Smith 
also argued against a scholastic style, recounting all aspects of a subject. Further, when trying to convey others' ideas, Smith regarded it as important to try to bring alive the spirit of the author. This enlivens our imaginations such that a sympathetic bond is built up between author and reader, between speaker and audience, which aids communication. Thus James Boswell (1785), the diarist, gives us an example based on his attendance at Smith's lectures on rhetoric. He remembered the pleasure Smith said he felt, when reading Milton, in knowing that the author laced his shoes with latchets, rather than buckled them. So this story clearly appealed to Boswell's imagination too.

Smith paid attention to the experience of the audience and what would appeal to their imagination. This in turn required the author to use imagination to understand the reader's perspective. The main focus of rhetoric had previously been either on oratory (designed to instruct and persuade), or on style and use of figures of speech. But Smith extended the subject to include, not only oratory, but also historical, or narrative, discourse, as well as poetic discourse (see Howell 1975). This followed directly from the need to justify theories in relation to experience, so communicating theories also in relation to narration of experience. Persuasive discourse was thus an important part, but not the whole, of Smith's communicative discourse.

We can see an illustration of the idea of invoking the sympathy of the audience in Hume's Treatise (1739-40), where he aims to take rationalist argument as far as he can (but concludes with skepticism). Near the end of the first Book he states that, after grappling with metaphysical problems by means of pure reason: 
I am confounded with all these questions, and begin to fancy myself in the most deplorable condition imaginable, invironed with the deepest darkness, and utterly deprived of the use of every member and faculty.

Most fortunately it happens, that since reason is incapable of dispelling these clouds, nature herself suffices to that purpose, and cures me of this philosophical melancholy and delirium, either by relaxing this bent of mind, or by some avocation, and lively impression of my senses, which obliterate all these chimeras. I dine, I play a game of backgammon, I converse, and am merry with my friends; and when after three or four hours' amusement, I would return to these speculations, they appear so cold, and strained, and ridiculous, that I cannot find in my heart to enter into them any farther.

Here then I find myself absolutely and necessarily determined to live, and talk, and act like other people in the common affairs of life.

Hume (1739-40: 269)

This conjures up a lovely picture of the person the French referred to as "le bon David", out for an evening's entertainment in Edinburgh's Old Town with his friends (see further Graham's, 2004, biography). But it is also persuasive in fostering the view he came to about the need to ground metaphysics in real experience which, as we have seen, was to prove important for the development of ideas about economics and about rhetoric.

Smith approached rhetoric as he approached all subjects, attempting to identify a system - something which he clearly found appealed to his own imagination (Skinner 
1996). His system of rhetoric was integral to his philosophy more generally (Berry 1974). As Bryce puts it in his Introduction to the Lectures on Rhetoric and Belles Lettres (Smith 1762-3: 25), “The primacy he gives to language ... rests on his vision of language as the embodiment of the mind's striving towards the 'metaphysical', towards conceptualization". One of the students in Smith's logic class in Glasgow, John Miller, put his impressions of the lectures on rhetoric as follows: "the best method of explaining and illustrating the various powers of the human mind, the most useful part of metaphysics, arises from an examination of the several ways of communicating our thoughts by speech, and from an attention to the principles of those literary compositions, which contribute to persuasion and entertainment..." (Royal Society of Edinburgh 1794: 61-2). In rhetoric, as in other areas, Smith was able to put together new ideas, which were being formulated more widely in Scotland in such a new and systematic way that his rhetoric was highly persuasive. As Tribe (1999: 618) puts it, "he treated the domain of rhetoric as equivalent to human communication, and therefore a pathway to an understanding of human motivation”.

While theories, in the Scottish approach to science, were derived from detailed study of experience, the communication of theories did not need to follow the same sequence. Indeed Smith argued that presenting theories as being derived from first principles was more persuasive than treating each experience in isolation - even if that is not how theories are arrived at (Skinner 1996). Smith thus understood well why Descartes's ideas had been so persuasive. Nevertheless, being unpersuaded himself by Descartes's rationalism, Smith regarded Descartes's physics as "one of the most entertaining romances that have ever been wrote" (Smith 1762-63a: 146). This 
distinction between how ideas are arrived at and how they are communicated will prove to be important for how Smith himself came to be understood.

\section{Rhetoric and Economic Theory}

We can see an example of this disparity between the formation of ideas and their communication in Smith's (1776) most famous work, An Inquiry into the Nature and Causes of the Wealth of Nations. One of the principles which Smith had derived from his detailed historical study was the principle of the division of labour. Wealth is created as a result of specialisation; this was one of the main reasons for arguing for free trade - that it allowed for more specialisation and thus higher productivity. But, instead of arriving at this conclusion late in the work, Smith started the first chapter with the division of labour, as if it were one of Descartes's axioms. He explained it in terms of an example which some regard as apocryphal: the pin factory. This example appeals to our imaginations we can imagine how difficult it would be for each of us to make our own pins, compared to a factory, where production is broken down into specialist steps. Further examples are given which reinforce our acceptance of the principle. Then the implications of the principle of the division of labour are drawn out.

I have just referred to Adam Smith's own communications. But communication of ideas was itself seen by Smith and Hume as integral to economic development (Dow and Dow 2008). ${ }^{13}$ Trade itself requires successful communication between buyer and seller there must be some capacity to understand the other's point of view in order to engage in successful trade, even while pursuing self-interest. Further, trade exposes importers to new ideas about consumption, which sparks off ideas about possibilities for local 
production; thus other countries catch up with the first developers. Also the division of labour is enhanced by new ideas about developing production techniques which arise from communication. Workers learn new practices and forms of self-discipline in the workplace through communication (Wennerlind 2006).

Hume and Smith also studied how communication goes through its own process of development as an integral element of social and economic development - the organic view of language (Berry 1974). This compounds the difficulty in understanding older texts. Smith speaks across the centuries, but is not necessarily understood in the same way. Indeed the interpretations of Smith are legion, differing at a range of levels, as Samuels (2009) explains with respect to the invisible hand. In the next section we draw on our understanding of Smith's rhetorical theory to help us understand the different interpretations of Smith, focusing on the invisible hand, the impartial spectator and the theory of economic development.

\section{Modern interpretation of Smith}

Smith is most commonly associated with the concept of the invisible hand, a metaphor, which appeals to the imagination, for the apparently spontaneous successful workings of free market economies made up of selfish individuals (Tribe 1999). But we only have to reflect on the well-known influence of Smith on Marx (a connection emphasised by Heilbroner 1986) to appreciate the scope for different readings of Smith, such that we cannot reasonably classify him as an out-and-out free marketeer. Indeed the conventional understanding in the modern history of economic thought literature is that the expression above of the invisible hand concept is misleading (see eg Winch 1997). As Evensky 
(2005: chapter 10) puts it, we can differentiate between the "Chicago Smith" and the "Kirkcaldy Smith". On the one hand, self-interest is now understood to be conditioned by moral sentiments rather than being equivalent to selfishness, and on the other hand Smith noted the tendency for free competition to be limited. Indeed the one use of the term "invisible hand" in the Wealth of Nations (Smith 1776: IV.ii.9) refers to the unintended consequences of bias in favour of domestic over foreign direct investment. This is intended as an indication of the scope for different interpretations: Samuels demonstrates the many and subtle differences in which the invisible hand has been interpreted.

Nevertheless the general equilibrium interpretation became embodied in much of modern economics, deduced from axioms of selfish rational individual behaviour (see eg Arrow and Hahn 1971). So, arguably, what has happened is that Smith's rhetoric was mistaken for his scientific method. Smith arrived at his (provisional) principles based on detailed study of societies, but presented them as if on the basis of established principles which could be treated as axioms. Indeed Smith (1762-63a: 146) noted how appealing argument from first principles could be, being more persuasive than the Aristotelian style. But the distinction between (provisional) principles and axioms had not been successfully conveyed. So Smith would in fact have understood why his system was interpreted as Cartesian, even if that conflicted with everything else he wrote - about scientific method and about human nature. This also meant that his economic theory has been open to the interpretation, from a Cartesian perspective, of being the forerunner of general equilibrium theory (see Montes 2005).

However Smith's system of rhetoric was after all intended as a contribution to metaphysics, since communication and persuasion were essential aspects of the 
production of knowledge which rests on social convention, including conventional belief.

Because truth was inaccessible, the notion of true axioms was ruled out. So, rather than presenting free-market principles as universals, in fact he pointed out ways in which market functions might be eroded - by producers trying to limit competition (Smith 1776: 84, 267), or by workers' lives being blighted by repetitive tasks (ibid.: 782), for example. His conclusions for economic theory and policy were provisional, and open to the need for change in different circumstances. Smith was forceful in his rhetoric - he was keen to persuade; but this is perfectly compatible with an acceptance that Smith was offering theories which were not "true", and certainly not universally true, even if he thought they were the most persuasive according to his own imagination and experience.

Smith's notion of the impartial spectator provides another example of a concept which has been the subject of a range of interpretations. For Smith, knowledge was founded on sentiment and imagination, as well as experience. A major motivation in the eighteenth century for analysing the emerging specialised market economies was the concern that they would erode moral values (see eg Hont and Ignatieff, eds, 1983 on the Scottish enlightenment, and Young 1997 specifically on Smith). In The Theory of Moral Sentiments, Smith (1759) explored the intrinsically social aspect of human nature, where sympathy plays a crucial role. It is sympathy with an imagined impartial spectator, as much as with the opinion of our neighbours, which keeps us in moral check (Raphael 1985, Griswold 2006). It is now generally agreed among Smith scholars that the selfinterested individual of the Wealth of Nations is consistent with the social being of the Moral Sentiments, bound by moral constraints embodied in the imagined judgement of the impartial spectator (Winch 1997, McCloskey 2008). 
This understanding of Smith comes from taking seriously his system of rhetoric, and applying it to his own work. What we have now was published posthumously, based on students' notes which only emerged in 1961. Had Smith had more confidence in his own thoughts on rhetoric, and his lectures published earlier, then perhaps his own use of rhetoric, and its connection with his moral philosophy, would have led to a different interpretation of his economics. However it is only recently that economists beyond the history of economic thought have extended their attention to The Theory of Moral Sentiments, and this has tended to be constrained by considering it in terms of a framework which is closer to Cartesian than Smithian. Thus for example Ashraf et al (2005) interpret the impartial spectator, not as a source of moral restraint, but as the vehicle for rationality to prevail over sentiment in the long run. Alternatively Binmore (2005: 50) provides another interpretation of the impartial spectator as the exogenous imposer of some absolute concept of the Good. But Smith had emphasised in his theory of rhetoric the importance of imagination and (moral) sentiment, conditioned by the social nature of our understanding (alongside reason), for the successful communication of ideas. Moral judgement is neither reason overcoming sentiment, nor externally imposed, but rather the result of "judgement being shaped by the views of others" (Broadie 2006: 158). This applies to internal communication with an imagined moral arbiter as much as to external communication of a speaker with his audience.

We might also have had for longer a better understanding of the Scottish enlightenment thought on progress, and comparisons between different societies. Scottish thought on economic development is often portrayed as a matter of inevitable progress from one stage to another. But, when the Scottish thinkers discussed the sequence of 
stages of social and economic development, it was clear that they did not see it in that way. They referred to other societies at earlier stages of economic development, with respect, and in fact addressed the problem that moral values might be eroded in later stages of development (Meek 1976). This reflected not only the Scottish theory of knowledge, but also their sense of "otherness" with respect to other societies in spite of the commonalities in human nature. This sense of "otherness" arguably underpinned their epistemology (particularly the inaccessibility of absolute truth) and their methodology

(particularly a focus on the provisionality of principles). ${ }^{14}$ Adam Ferguson (1767), the father of modern sociology, was particularly concerned that the socio-economic system would self-destruct as the social fabric was eroded by increasing commercialisation. He was a Highlander and Gaelic speaker who would have been aware even more than his Lowland friends of the dangers of making judgements about different social systems as indicating savagery.

\section{Conclusion}

If nothing else, the theory of knowledge in the Scottish Enlightenment allowed for different approaches to, and versions of, knowledge. Social convention and moral values were critical to the successful functioning of society; reason alone was inadequate as a basis for improvement. This provided the basis for respect for difference. The system of rhetoric provided grounding for successful communication in spite of difference. The connection made between communication and understanding could still stand us in good stead in modern economics. 


\section{References}

Arrow, K J and Hahn, F H (1971) General Competitive Analysis. San Francisco: HoldenDay and Edinburgh: Oliver \& Boyd.

Ashraf, N, Camererer, C F and Loewenstein, G (2005) “Adam Smith, Behavioural Economist", Journal of Economic Literature 19(3).

Berry, C (1974) “Adam Smith's Considerations on Language” Journal of the History of Ideas 35 (1): 130-8.

Binmore, K (2005) Natural Justice. Oxford: Oxford University Press.

Boswell, J ([1785] 1925) The Journal of a Tour to the Hebrides with Samuel Johnson, LL.D. London: T Nelson.

Boyle, R. ([1661] 1965) Some considerations Touching the Style of the Holy Scriptures, in T Birch (ed.), The Works of the Honourable Robert Boyle, vol. 2. Hildersheim: Georg Olms.

Broadie, A (2006) “Sympathy and the Impartial Spectator”, in K Haakonssen (ed.) The Cambridge Companion to Adam Smith. Cambridge: Cambridge University Press.

Brown, V (1994) Adam Smith's Discourse: Canonicity, Commerce and Conscience. London: Routledge.

Buchan J (2003) Capital of the Mind: How Edinburgh Changed the World. Edinburgh: John Murray.

Burns, R ([1786] 1990) “Tae a Louse”, in The Complete Illustrated Poems, Songs and Ballads. London: Chancellor, pp. 141-2. 
Carabelli, A (1988) On Keynes's Method. London: Macmillan.

Comim, F (2006) "Scottish Common Sense Philosophy", in A Dow and S Dow (eds), A History of Scottish Economic Thought. London: Routledge, 123-45.

Dow, A and Dow, S (2008) "Theories of Economic Development in the Scottish Enlightenment", in P E Earl and B Littleboy (eds), Regarding the Past. Brisbane: University of Queensland, pp. 9-24.

Dow, S (2001) "Hume: A Re-assessment”, in P L Porta, R Scazzieri, and A S Skinner (eds), Knowledge, Division of Labour and Social Institutions, Elgar, 75-92.

Dow, S (2009) “Smith's Philosophy and Economic Methodology”, in J T Young (ed.), Elgar Companion to Adam Smith. Cheltenham: Edward Elgar.

Emerson, R L (2008) “The Scottish Contexts for David Hume's Political-Economic Thinking", in C Wennerlind and M Schabas (eds), David Hume's Political Economy. London: Routledge.

Evensky, J (2005) Adam Smith's Moral Philosophy. Canbridge: Cambridge University Press.

Ferguson, A ([1767] 1967) Essay on the History of Civil Society, edited by D Forbes. Edinburgh: Edinburgh University Press.

Gerrard, B (1992) "Human Logic in Keynes's thought: Escape from the Cartesian Vice", in P Arestis and V Chick (eds), Recent Developments in Post-Keynesian Economics. Cheltenham: Edward Elgar.

Graham, R (2004) The Great Infidel: A Life of David Hume. Edinburgh: Tuckwell.

Griswold, C L Jr (2006) “Imagination: Morals, Science, and Arts”, in K Haakonssen (ed.) 
The Cambridge Companion to Adam Smith. Cambridge: Cambridge University Press.

Heilbroner, R L (1986) The Essential Adam Smith. Oxford: Oxford University Press.

Hont, I and Ignatieff, M, eds (1983) Wealth and Virtue: The Shaping of Political

Economy in the Scottish Enlightenment. Cambridge: Cambridge University Press.

Howell, W S (1967) “John Locke and the New Rhetoric" Quarterly Journal of Speech 53: 319-33.

Howell, W S (1975) “Adam Smith's Lectures on Rhetoric: An Historical Assessment”, in A S Skinner and T Wilson (eds), Essays on Adam Smith. Oxford: Clarendon, 1143.

Hume, David ([1739-40] 1978) A Treatise of Human Nature, edited by K A Selby-Bigge and P H Nedditch, second edition. Oxford: Clarendon.

Kaul, N (2008) Imagining Economics Otherwise: Encounters with Identity/Difference. London: Routledge.

London Times (1790) “Obituary of Adam Smith”, 24 July.

McCloskey, D N (1986) The Rhetoric of Economics. Brighton: Wheatsheaf.

McCloskey, D N (1994) Knowledge and Persuasion in Economics. Cambridge: Cambridge University Press.

McCloskey, D N (2006) The Bourgeois Virtues: Ethics for an Age of Commerce. Chicago: Chicago University Press.

McCloskey, D N (2008) “Adam Smith, the Last of the Virtue Ethicists”, History of Political Economy 40(1), 43-71.

McCloskey, D N and Klamer, A (1995) “One Quarte of GDP is Persuasion”, American 
Economic Review 85(2), 191-5.

Meek, R L (1976) Social Science and the Ignoble Savage. Cambridge: Cambridge University Press.

Montes, L (2006) “Adam Smith: Real Newtonian”, in A Dow and S Dow (eds), A History of Scottish Economic Thought. London: Routledge, 102-22.

Raphael, D D (1985) Adam Smith. Oxford: Oxford University Press.

Rapin, R ([1864] [1706] 2009) The Whole Critical Works of Monsieur Rapin. Whitefish, MT: Kessinger.

Royal Society of Edinburgh (1794) Transactions, vol. iii, pt. I

Samuels, W J (ed.) (1989) Economics as Discourse: An Analysis of the Language of Economics. Boston: Kluwer.

Samuels, W J (2009) 'The Invisible Hand', in J T Young (ed.), Elgar Companion to Adam Smith. Cheltenham: Edward Elgar.

Skinner, A S (1976) “Adam Smith: The Development of a System”, Scottish Journal of Political Economy 23(2), 111-32.

Skinner, A S (1996) "Language, Rhetoric and the Communication of Ideas", in A System of Social Science: Papers Related to Adam Smith, second edition. Oxford: Clarendon, 7-24.

Skinner, Q (1969) “Meaning and Understanding in the History of Ideas”, History and Theory, 8: 3-53.

Smith, A ([1759] 1976) The Theory of Moral Sentiments, Glasgow edition, edited by D D Raphael and A Macfie, Oxford: Oxford University Press.

Smith, A ([1762-63a] 1983) Lectures on Rhetoric and Belles Lettres, edited by J C Bryce, 
Oxford: Oxford University Press.

Smith, A ([1762-63b] 1978) Lectures on Jurisprudence (A), edited by R L Meek, D D

Raphael and P G Stein. Oxford: Oxford University Press.

Smith, A. ([1776] 1976) An Inquiry into the Nature and Causes of the Wealth of Nations, edited by R H Campbell and A S Skinner, Oxford: Oxford University Press.

Smith, A. ([1795] 1980) “The History of Astronomy", in Essays on Philosophical

Subjects, edited by W L D Wightman Oxford: Oxford University Press.

Sprat, T. (1667) The History of the Royal Society of London. London.

Tribe, K (1999) “Adam Smith: Critical Theorist?”, Journal of Economic Literature 37(2),

$609-32$.

Wennerlind, C (2006) "David Hume as a Political Economist", in A Dow and S Dow (eds), A History of Scottish Economic Thought. London: Routledge, 46-70.

Winch, D (1997) “Adam Smith's Problem and Ours”, Scottish Journal of Political Economy 44 (4): 384-402.

Young, J T (1997), Economics as a Moral Science: The Political Economy of Adam Smith, Cheltenham: Edward Elgar.

\footnotetext{
${ }^{1}$ This paper has benefited from the comments and suggestions of Deirdre McCloskey and two anonymous referees.

${ }^{2}$ For example in Rapin's (1684) rhetorical study.

${ }^{3}$ This development arose from the work of Boyle (1663), Sprat (1667) and Locke (see Howell 1967).

${ }^{4}$ See further http://deirdremccloskey.org/for references to her other extensive writing in this area.

${ }^{5}$ While Brown (1994: chapter 2) argues that Smith did not address issues of meaning (and thus the scope for different meanings) in his Lectures on Rhetoric and Belles Lettres, a study of his work as a whole provides a better understanding of these issues.

${ }^{6}$ This is the case, even allowing for the increased interest now in his Theory of Moral Sentiments; issues of interpretation arise here as with Smith's economics.

${ }^{7}$ Keynes's philosophy was significantly influenced by Hume; see Carabelli (1988).

${ }^{8}$ McCloskey (2006) explores the significance of moral sense in Scottish ethical theory, in contrast to Kant and Bentham's inability to explain the motivation behind ethics.

${ }^{9}$ Newton would provide another case study for different interpretations from different epistemological perspectives, in this case the perspectives of England and France, compared to Scotland.
} 
${ }^{10}$ Because (inevitably) partial evidence leaves gaps to be filled by conjectures, this approach is sometimes referred to as conjectural history.

${ }^{11}$ In translation (by the present author) from Scots: "O would that some Power would give us the gift of seeing ourselves as others see us".

${ }^{12}$ It is Smith's emphasis on the value of the plain style which Brown (1994) argues suppresses issues of meaning, while he in fact employs figures of speech himself in the Lectures on Rhetoric and Belles Lettres.

${ }^{13}$ See McCloskey (1994: 77-83); McCloskey and Klamer (1995) and McCloskey (2006: 306-7) for more general statements of this argument.

${ }^{14}$ The importance more generally of the sense of otherness has been most fully developed by Kaul (2008, chapter 2 and 3 ). 